\title{
IS NOVAMIN TOOTHPASTE EFFECTIVE ON ENAMEL REMINERALIZATION? AN IN-VITRO STUDY
}

\section{ABSTRACT}

Objectives: New bio-active glass containing toothpaste (NovaMin) is one of the most effective cariostatic products when used as a daily application the aim of this in-vitro study is to evaluate the influence of NovaMin on enamel remineralization.

Materials and Methods: Twenty-eight sound human enamel samples were randomly divided into four groups (A-D) each having seven samples as follows: A (Novamin), B (1450 ppm NaF and Novamin), C (CPP-ACP), D (1450ppm NaF). After inducing caries-like lesions, each group was maintained daily for demineralizationremineralization cycle for seven days. During this cycle, samples were treated by the selected toothpaste for each group. Enamel mineral loss was assessed by surface microhardness. Surface enamel microhardness was determined on the enamel blocks. Non-parametric Kruskar-Wallis test compares the amount of surface microhardness recovery (SMHR\%) across four different toothpastes.

Results: PLM data revealed a mineral precipitation band on the surface layer of all toothpastes; however, when compared to treated lesions, no statistically differences among the groups $(\mathrm{p}>0.05)$ were found.

Conclusions: NovaMin containing dentifrice has similar remineralization potential on carious-like lesions when compared to fluoride containing dentifrices.

Keywords: Toothpaste, tooth remineralization, tooth demineralization, in vitro techniques, tooth

\author{
*Zerrin Abbasoğlu ${ }^{1}$ \\ (DDamla Akşit Bıçak ${ }^{2}$ \\ (DDilara Özenay Dergin ${ }^{3}$ \\ DDidem Kural ${ }^{3}$ \\ (Dilknur Tanboğa ${ }^{3}$
}

${ }^{1}$ Lecturer, Department of Pediatric Dentistry,
Faculty of Dentistry, Yeditepe University,
Istanbul, Turkey
${ }^{1}$ Fellow, Division of Orthodontics, Faculty
of Dentistry, University of Connecticut,
Farmington, USA
${ }^{2}$ Lecturer, Department of Pediatric Dentistry,
Faculty of Dentistry, Near East University,
Nicosia, North Cyprus
${ }^{3}$ Department of Pediatric Dentistry, Faculty
of Dentistry, Marmara University, Istanbul,
Turkey

Received : : 10.06 .2018

Accepted $\quad: 18.12 .2018$

\footnotetext{
How to Cite: Abbasoğlu Z, Bıçak DA, Dergin DÖ, Kural D, Tanboğa İ. Is Novamin Toothpaste Effective on Enamel Remineralization? An In-Vitro Study. Cumhuriyet Dent J 2019;22:1:22-30. 


\section{INTRODUCTION}

Preventive dentistry is one of the most preferred research subjects. In many of in situ and in vivo research projects in cariology, laboratory tests are used to examine dental caries, especially the impact of fluoride $(\mathrm{F})$ on prevention of enameldentin demineralization and enhancement of remineralization. ${ }^{1-4}$

Demineralization is the first step in dental decay process, while remineralization controls and reverses the decay process. Demineralization occurs when the acidogenic bacteria reduce $\mathrm{pH}$ of the calculus. On the other hand, when $\mathrm{Ca}^{+2}$ and $\mathrm{PO}^{-3}$ ions in saliva increase the $\mathrm{pH}$ in calculus, remineralization process allows demineralized lesions to become remineralized. When demineralization is equal to or higher than remineralization, decay occurs. ${ }^{5}$

The buffer capacity of the saliva depends on the concentration levels of its $\mathrm{Ca}^{+2}$ and $\mathrm{PO}^{-3}$ ions. The amount of remineralization increases when the fluoride ions are in the saliva. Therefore, studies that deal with the prevention of caries and reversing the decay or the demineralization process are focused on the role of fluoride ions.

Some toothpastes include different formulas which are biocompatible with tooth structure chemically, and aim to decrease demineralization, prevent adhesion of bacteria on teeth, provide remineralization and prevent the sensitivity of dentin. According to most researchers, toothpastes that contain a similar dose of fluoride (500-1000 ppm) provide approximately the same effect on demineralization; however, fluoride concentrations of $500 \mathrm{ppm}$ and under are accepted as minimum dose and have minimal effect on demineralization. ${ }^{6,7}$

The $\mathrm{pH}$ cycling model mimics mineral loss and remineralization procedures, needing smaller sample size and the response variables that can be employed in $\mathrm{pH}$-cycling models are more sensitive than those available for use in the clinical situation. ${ }^{8,9}$ In $\mathrm{pH}$-cycling test, artificial enamel lesions are treated with oral hygiene products in demineralization and remineralization cycles to mimic oral $\mathrm{pH}$-fluctuation patterns. ${ }^{10,11}$
Recently, bioactive glass materials have been introduced in many fields of dentistry. This material has numerous novel features the most important of which are its ability to act as a biomimetic mineralizer matching the body's own mineralizing traits while also affecting cell signals in a way that benefits the restoration of tissue structure and function. ${ }^{12}$ Bioactive glass isconsidered to be a breakthrough in remineralization technology; it is a multicomponent inorganic compound made up of elements such as silicon, calcium, sodium and phosphorus. ${ }^{13}$ The active ingredient is amorphous calcium sodium phosphosilicate. This compound in an aqueous environment release bioavailable calcium, sodium and phosphate ions contributing to the remineralization process. ${ }^{14}$ However, the remineralization potential of bioactive glass has so far not been evaluated and compared with fluoride, CPP-ACP and bioactive glass with fluoride using an in-vitro $\mathrm{pH}$ cycling method. Artificial early caries like lesions of enamel show all the principal histological features of natural caries and are a useful analog for natural lesions when studying demineralization and remineralization of enamel invitro ${ }^{15}$ Hence the aim of this in-vitro study is to investigate the efficacy of bioactive glass containing toothpaste (Novamin) on remineralization of artificial incipient enamel lesion using $\mathrm{pH}$ cycling method.

\section{MATERIALS AND METHODS}

\section{Enamel Block Preparation}

A total of 28 human molar teeth were extracted due to periodontal problems. The soft-tissue debris on the teeth were cleaned and inspected for intact surfaces that are free from caries, hypoplasia, and white spot lesions.

35 enamel blocks $(2 \times 3 \mathrm{~mm})$ were formed from extracted human teeth using a diamond bur and kept in $2 \%$ formaldehyde solution at $\mathrm{pH}$ 7.0. ${ }^{9}$ The specimens were embedded in the epoxy resin and the surface of the enamel blocks were grounded flat. Later the buccal surface of enamel blocks were polished using a 1.2 grit waterproof silicon carbide paper and water-cooled carborundum discs so that $50 \mu \mathrm{m}$ of the surface layer was removed and controlled with a digital 
micrometer. The prepared samples were submitted to the microhardness test.

\section{NovaMin- Toothpaste Evaluation}

After treatment with different experimental dentifrices, enamel blocks were randomly selected into four groups of seven; in group A: teeth were treated with Dr. Collins Restore Toothpaste
(NovaMin); in group B: teeth were treated with Sensodyne Repair And Protect Toothpaste (1450 ppm $\mathrm{NaF}$ and NovaMin); in group $\mathrm{C}$ : teeth were treated with Gc Toothmousee (CPP-ACP); for group D: teeth were treated with Sensodyne ${ }^{\circledR}$ Pronamel' ${ }^{\mathbf{T M}}{ }^{\circledR}$ for Chidren (1450 ppm NaF). The ingredients of the experimental toothpastes are displayed in Table 1.

Table 1. Remineralizing agents used in the study

\begin{tabular}{|l|l|}
\hline Materials & Ingredients* \\
\hline $\begin{array}{l}\text { Dr.Collins Restore } \\
\text { Toothpaste (NovaMin) }\end{array}$ & $\begin{array}{l}\text { Glycerin, Amorphous Silica, PEG 400, Sodium Lauryl Sulphate, Mint Flavor, } \\
\text { Carbomer, Potassium Acesulfame, Titanium Dioxide, Novamin (Calcium Sodium } \\
\text { Phosphosilicate) }\end{array}$ \\
\hline $\begin{array}{l}\text { Sensodyne Repair and } \\
\text { Protect Toothpaste }\end{array}$ & $\begin{array}{l}\text { Purified water, sorbitol, Liquid (non-crystallising), Silica, Dental type, Glycerol, } \\
\text { Macrogols, Xanthan Gum, Titanium Dioxide (E171), Cocamidopropyl Betaine, } \\
\text { Saccharin Sodium, Sodium Hydroxide, Titanium Dioxide, Flavour Blend 10926, } \\
\text { Sodium Fluoride, Potassium Nitrate }\end{array}$ \\
\hline GC Tooth Mousee & $\begin{array}{l}\text { Pure water, CPP-ACP, D-sorbitol, CMC-Na, glycerol, propylene glycol, silicom } \\
\text { dioxiode, titanium dioxide, xylitol, phosphoric acid, flavoring, zinc oxide, sodium } \\
\text { saccharin, ethyl p-hydroxy benzoate, magnesium oxide, guar gum, propyl p-hydroxy } \\
\text { benzoate, butyl p-hydroxy benzoate }\end{array}$ \\
\hline Sensodyne Pronamel & $\begin{array}{l}\text { Purified water, sorbitol, Liquid (non-crystallising), Silica, Dental type, Glycerol, } \\
\text { Macrogols, Xanthan Gum, Titanium Dioxide (E171), Cocamidopropyl Betaine, } \\
\text { Saccharin Sodium, Sodium Hydroxide, Mint Flavour 10926 }\end{array}$ \\
\hline
\end{tabular}

*Informed by the manufacturers.

After inducing caries-like lesions, daily demineralization and remineralization cycles were applied for 7 days. After $\mathrm{pH}$ cycling, the surface was assessed, and the integrated loss of subsurface hardness calculated. Artificial caries-like lesions were formed on specimens of intact human enamel after demineralizing solution was applied for 32 hours.

\section{Toothpaste Treatments and Remineralizing $\mathrm{pH}$ - Cycling Model}

Samples were subjected to five $\mathrm{pH}$ cycles during 7 days at $37^{\circ} \mathrm{C}$ for each group. ${ }^{16}$ During $\mathrm{pH}$ cycling blocks were put in a demineralization solution [Demineralization solution in $75 \mathrm{mmol} / \mathrm{lt}$ acetate buffer, pH $4.7 ; \quad 2.2 \mathrm{ml} / \mathrm{mm}^{2} ; \quad 2.0 \mathrm{mmol} / \mathrm{lt}$ $\mathrm{Ca}\left(\mathrm{NO}_{3}\right)_{2} . \mathrm{H}_{2} \mathrm{O}, 2.0 \mathrm{mmol} / \mathrm{lt} \mathrm{NaH}_{2} \mathrm{PO}_{4} \cdot \mathrm{H}_{2} \mathrm{O}$ and $0.04 \mu \mathrm{g} \mathrm{F} / \mathrm{ml}(\mathrm{NaF})]$ for 6 hours and in a remineralization solution [Remineralization solution, in $0.1 \mathrm{~mol} / \mathrm{lt}$ cacodylate buffer, 7.01 .1 $\mathrm{ml} / \mathrm{mm}^{2} ; 1.5 \mathrm{mmol} / \mathrm{lt} \mathrm{Ca}\left(\mathrm{NO}_{3}\right)_{2} . \mathrm{H}_{2} \mathrm{O}, 0.9 \mathrm{mmol} / \mathrm{lt}$ $\mathrm{NaH}_{2} \mathrm{PO}_{4} \cdot \mathrm{H}_{2} \mathrm{O}, 150 \mathrm{mmol} / \mathrm{lt} \mathrm{KCl}$ and $0.05 \mu \mathrm{g}$ $\mathrm{F} / \mathrm{ml} \mathrm{NaF}$ for 18 hours. The treatment included a bi-daily 1-minute soak in $2 \mathrm{ml} / \mathrm{block}$ of toothpaste/deionized water slurries $(1: 3 \mathrm{w} / \mathrm{w})$ under agitation daily before the solution was changed from demineralization to remineralization or vice versa. Deionized water was applied before each step. Samples were kept in the remineralization solution for 2 days. This $\mathrm{pH}$ Cycling model was developed by Vieira et al. ${ }^{16}$

\section{Hardness Analysis}

The hardness of the enamel surface was determined via the Surface Microhardness Analysis (SMH) before and after $\mathrm{pH}$ cycling with a Digital Micro-Vickers Hardness Tester (Wilson Wolpert; Europe BV, 401 MVD, Netherland). The Digital Micro-Vickers Hardness Tester was fitted with a Vickers diamond and 25 gram load was used to make indentations on the enamel surface. The loaded diamond was allowed to rest on the surface for 10 seconds. ${ }^{17}$

Three indentations spaced by $100 \mu \mathrm{m}$ and in different parts of the enamel were taken at the baseline, and after the caries like lesion, after $\mathrm{pH}$ cycling SMH was again determined and percentage of SMH recovery (\%SMHR) was calculated $(\% \mathrm{SMHR}=[(\mathrm{SMH} 3-\mathrm{SMH})) /(\mathrm{SMH} 1-$ SMH2)]x100. ${ }^{18} \quad$ (SMH1: Baseline surface 
microhardness, SMH2: After 32 hours demineralization application, SMH3: After $\mathrm{pH}-$ Cycling)

\section{Statistical Analysis}

Statistical analysis was performed using the SPSS 15.0 software for Windows (SPSS Inc., Chicago, IL, USA). Since the data do not follow a normal distribution, Kruskal-Wallis test was employed to compare parameters between groups. Also parameters within each group were compared by Wilcoxon sign test. In both tests, $\mathrm{p} \leq 0.05$ was considered to be statistically significant.

\section{RESULTS}

The mean and SD values of enamel surface microhardness at baseline, after demineralization and after $\mathrm{pH}$ cycling with four different toothpastes were calculated.

In the groups the lowest value of the mean baseline surface microhardness was $5.28 \pm 0.63$ and the highest was $28.35 \pm 10.77$. Our results indicate that no statistically significant difference in mean microhardness levels existed across different toothpastes in either prior to or following demineralization $(p>0.05)$. Similarly, no statistically significant difference was observed neither for mean microhardness levels after the application of toothpaste, or after remineralization ( $p>0.05$ ).

For all four groups of toothpaste [i.e. Sensodyne Fluorine, Sensodyne repair, Toothmousse and Dr. Collins), the increase in microhardness from pre-demineralization levels to post-remineralization levels was statistically significant $\quad(p<0.05)$. The increase in microhardness from post-demineralization to posttoothpaste application levels was also statistically significant $(\mathrm{p}<0.05)$. Our results also suggest Novamin performs as well as other conventional toothpastes (Table 2).

Table 2. Assessment of microhardness according to types of toothpastes

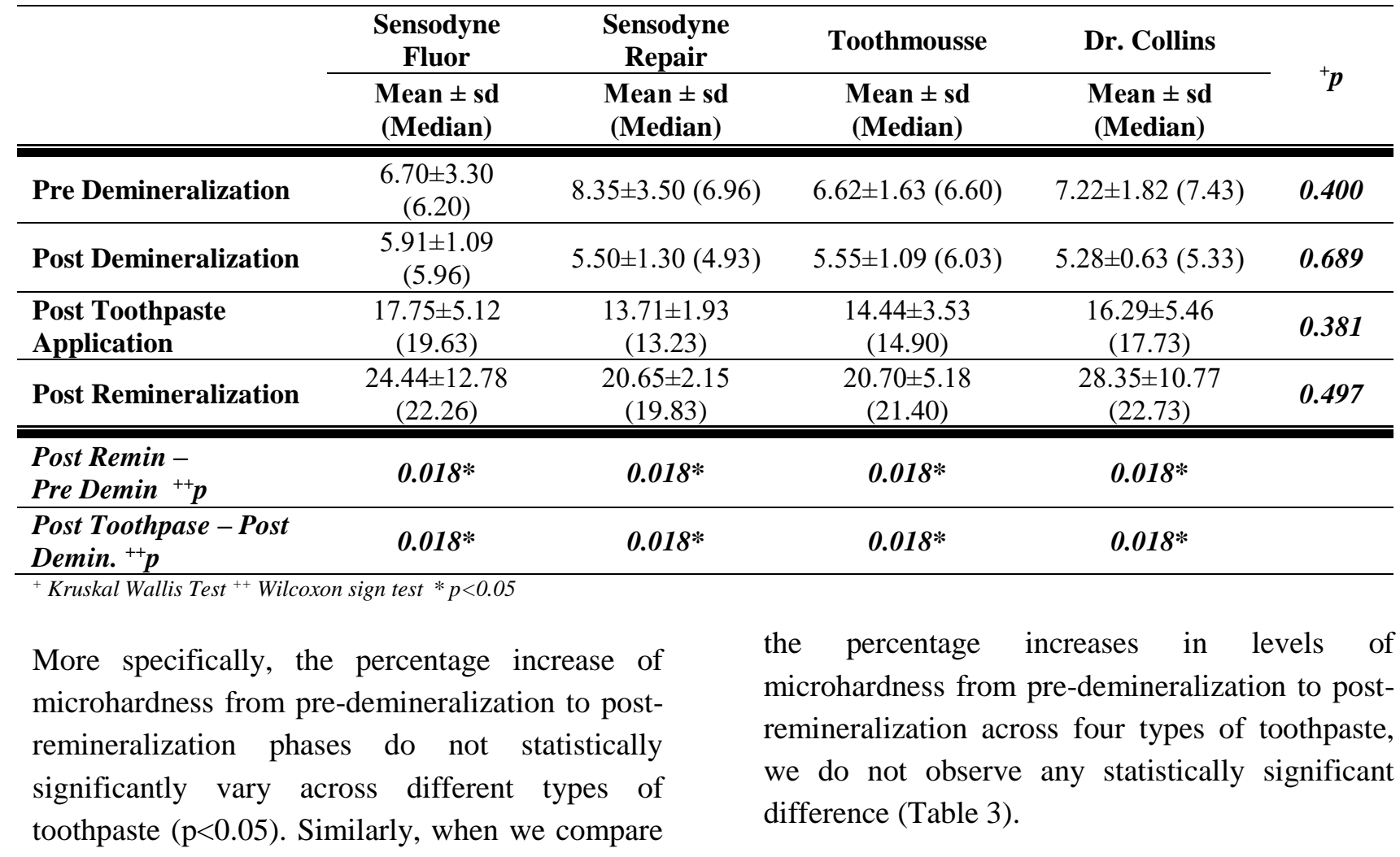


Finally, no statistically significant difference exists among these four types of toothpaste when the percentage increases in microhardness levels are compared from post-demineralization to posttoothpaste stage $(\mathrm{p}<0.05)$ (Table 4).

Table 3. Percentage increase from Pre-demin to Post-remin

\begin{tabular}{|c|c|c|c|c|c|c|}
\hline & Mean & p50 & p25 & p75 & sd & $p$ \\
\hline Dr. Collins & 325.76 & 263.93 & 133.68 & 467.31 & 215.95 & \multirow{5}{*}{0.495} \\
\hline Sensodyne Fluor & 303.22 & 304.73 & 121.45 & 362.50 & 207.77 & \\
\hline Sensodyne Repair & 178.68 & 195.97 & 120.24 & 212.80 & 98.24 & \\
\hline Toothmousse & 226.18 & 236.48 & 112.55 & 350.00 & 104.43 & \\
\hline Total & 258.46 & 221.04 & 127.56 & 347.96 & 167.74 & \\
\hline
\end{tabular}

Kruskal Wallis Test (Post remin-Pre demin* 100/Pre-demin)

Table 4. Percentage increase from Pre-Demin to Post-Toothpaste (post toothpaste-pre demin)*100/pre-demin)

\begin{tabular}{|c|c|c|c|c|c|c|}
\hline & Mean & p50 & p25 & p75 & sd & $p$ \\
\hline Dr. Collins & 141.49 & 133.26 & 21.94 & 242.86 & 105.22 & \multirow{5}{*}{0.174} \\
\hline Sensodyne Fluor & 191.86 & 194.00 & 85.45 & 248.39 & 105.29 & \\
\hline Sensodyne Repair & 80.37 & 68.97 & 45.83 & 109.90 & 52.89 & \\
\hline Toothmousse & 128.77 & 126.98 & 71.27 & 209.55 & 73.28 & \\
\hline Total & 135.62 & 122.11 & 65.37 & 201.77 & 91.50 & \\
\hline
\end{tabular}

Kruskal Wallis Test

\section{DISCUSSION}

Minimal invasive approaches that preserve healthy tooth structure have gained importance in dental practice in recent years. ${ }^{19,20}$ Remineralization is the deposition of calcium, phosphate and other ions in the demineralized region. ${ }^{21,22}$ Toothpastes containing new remineralization agents can be used due to their easy application, low cost and ability to prevent dental caries formation with their remineralizing properties. ${ }^{19,20}$

Fluoride has positive effects on dental caries, as well as toxic effects, which limit its use and its amount. It is widely accepted that fluoride is the most effective agent in protection against dental caries. However, there has been increasing debate over the use of fluoride in recent years. For this reason, studies towards different remineralization agents that are safer and as effective as fluoride have gained importance. ${ }^{23}$ Therefore, we investigated the effectiveness of newly developed alternative remineralization agents, which is one of the most emphasized topics in today's preventive dentistry.
Novamin, also known as calcium sodium phosphosilicate, is a white, powdery, highly biocompatible compound that comes from the combination of body-produced minerals and bioactive glass. ${ }^{24}$ Novamin reacts when it comes into contact with liquids, such as water, saliva, and releases calcium, sodium, phosphorus, and silica into the solution, resulting in hydroxycarbonate apatite crystals similar to the hydroxyapatite crystals that make up the mineral composition of enamel. ${ }^{25}$ Bioactive glasses provide release of calcium and phosphate ions in the oral environment. Gjorgievska et al. ${ }^{26}$ stated that toothpaste with bioactive glass gives successful results in hard tissue repair. Matsuyoshi et $a .^{27}$ found that toothpastes containing bioactive glass successful in terms of remineralization.

A number of studies, similar to ours, have focused on remineralization effect of Novamin. Palaniswamy et $a .^{28} 2016$ compared the remineralization potential CPP-ACP (GC Tooth Mousse), Novamin and fluoride containing 'Sensodyne Repair and Protect' named toothpaste. The samples were tested for microhardness. Sensodyn Repair and Protect showed better results 
initially, but eventually both had similar remineralizing potential as in the present study. ${ }^{28}$ Also, Mony et al. ${ }^{29} 2015$ found that NovaMin was effective in improving the $\mathrm{Ca} / \mathrm{PO} 4$ ratio and hardness in a demineralized enamel as fluoride. Similarly, we found that Novamin can be a new alternate material for remineralization of enamel.

In another in-vitro study, when they compared the remineralizing potential of four commercially available products namely SHYNM (Novamin), GC Tooth Mousse Plus (CPP$\mathrm{ACP}$ and $900 \mathrm{ppm}$ fluoride), ReminPro (hydroxyapatite $1450 \mathrm{ppm}$ fluoride and Xylitol) and Colgate strong teeth (1000 ppm fluorid) on demineralized human teeth, SHY-NM had the most remineralizing potential followed by ReminPro, GC Tooth Mousse Plus and fluoridated toothpaste. ${ }^{30}$ Mettu et al. ${ }^{31}$ reported that CPP-ACP increases enamel surface hardness. In a study, the CCP-ACP paste showed remineralizationinducing effect on artificially induced initial caries lesions. It was observed that this effect increased in direct proportion to the duration of application. Narayana et al. $^{32} 2014$ found that Bioactive glass (SHY-NM) showed more remineralization potential than Fluoride tooth paste (Amflor), CPPACP (Tooth mousse), CPP-ACPF (Tooth mousse plus) using an in-vitro $\mathrm{pH}$ cycling method. In another contemporary study, the potential remineralization effect of topical NovaMin and Sodium Fluoride gel on caries like lesions in permanent teeth were compared. Specimens were then evaluated by a Surface Micro Hardness test. The researchers demonstrated that NovaMin dentifrice had a greater effect on remineralization of carious-like lesions when compared to that of fluoride containing dentifrice in permanent teeth. $^{33}$ However, Dr. Collins toothpaste (Novamin) showed similar remineralization potential to other dentrifices in our study. The differences on results between our study and other studies may be related to the ingredients of products or different amount of Novamin.

Furthermore, Mehta et $a l^{34}$, compared the remineralization potential of Novamin and CPPACP containing dentrifice. The baseline surface microhardness was measured using the vickers microhardness testing machine for all the specimens. Artificial enamel carious lesions were created by inserting the specimens in demineralizing solution and 10 days of $\mathrm{pH}$ cycling regimens was carried out. Although Novamin and CPP-ACP were found effective on remineralizing early enamel caries as in our study, the researchers demonstrated that novamin was more effectively remineralized the carious lesion when compared with CPP-ACP. Similarly, another study showed that Sensitive Pro-Relief and NovaMin ${ }^{\circledR}$ presented an advantage in enhancing remineralization and inhibiting demineralization for early enamel carious lesions in comparison with GC Tooth Mousse. ${ }^{35}$ In our study both novamin and CPP-ACP containing dentrifices had similar effects in remineralization process ( $\mathrm{p}>0.05)$.

Microhardness evaluations, either superficial or cross-sectional, imply quantitative measures that can evaluate minimum changes on mineral content and it is a widely used method and together with intra-oral models, has great importance in de- and re-mineralization experiments. ${ }^{36,37}$ In this study, microhardness measurements after demineralization and after $\mathrm{pH}$ cycling are used to determine demineralization and remineralization changes on enamel surface. When the effects of toothpastes containing different remineralization agents on the surface microhardness were examined, it was observed that all agents used in this study had similar remineralization abilities. Our results indicated that no statistically significant difference in mean microhardness levels existed across different toothpastes in either prior to or following demineralization. Similarly, no statistically significant difference was observed either for mean microhardness levels after the application of toothpaste, or after remineralization. For all four groups of toothpaste (novamin contaning toothpaste, novamin and fluoride containing toothpaste, CPP-ACP containing paste and Fluoride-containing toothpaste) used in this study, the increase in microhardness from predemineralization levels to post-remineralization levels was statistically significant. The increase in microhardness from post-demineralization to post- 
toothpaste application levels was also statistically significant. More specifically, the percentage increase of microhardness from predemineralization to post-remineralization phases did not statistically vary across different types of toothpaste. Similarly, when we compared the percentage increased in levels of microhardness from pre-demineralization to postremineralization across four types of toothpaste, we didn't observe any statistically significant difference. Finally, no statistically significant difference was observed among these four types of toothpaste when the percentage increase in microhardness levels is compared from postdemineralization to post-toothpaste stage.

In all of the in vitro studies ${ }^{28-35,38}$ described above in which human teeth were used; all researchers demonstrated Novamin as an effective remineralizing agent as in our study, but there were some differences found between the studies, such as novamin which was found more effective in some studies ${ }^{34,} 35$ or less effective in other studies than dentrifices including fluoride and CPP-ACP. Some studies found no statistical differences between dentrifices in remineralizing potential as in our study. ${ }^{28,29}$ The reason for these findings might be differences in $\mathrm{pH}$-cycling regimens, microhardness evaluation methods, different ingredients of pastes, different mechanisms of remineralization processes of agents, differences in the forms and amounts of dentrifices used and differences in the tooth structures in these studies.

\section{CONCLUSIONS}

It was determined that all the remineralization materials applied to the initial enamel carious lesions prepared artificially on the enamel surface had statistically significant remineralization effect and these remineralization materials can be successfully used in cases of initial enamel caries.

Toothpastes used in this study were effective in maintaining remineralization after $\mathrm{pH}$ cycling but no difference was observed among the groups.
There was no significant difference among groups in surface microhardness value after $\mathrm{pH}$ cycling.

NovaMin dentifrice appears to have an effect on remineralization of carious-like lesions similar to that of fluoride and CPPACP containing dentifrices. Therefore novamin-containing products can be used as an alternative to fluoride and CPP-ACP.

More extensive scientific studies are needed to prevent the formation of dental caries or to develop effective agents in the initial stages of treatment. Our study may direct future researchers to conduct new studiesfor this purpose.

\section{ACKNOWLEDGEMENTS}

None

\section{CONFLICTS OF INTEREST}

None

\section{Novamin Diş Macunu, Mine Remineralizasyonu Üzerine Etkili Mi? Bir İn-Vitro Çalışma}

$\ddot{O} Z$

Amaç: Yeni biyo-aktif cam içerikli diş macunu (Novamin) günlük diş macunu olarak kullanıldı̆̆ında etkili diş çürüğ̈̈ oluşumunu azaltan ürünlerden birisidir. Bu in-vitro çalışmanın amacl, Novamin'in mine remineralizasyonu üzerindeki etkisinin değerlendirilmesidir. Gereç ve Yöntemler: 28 sağlam insan diş minesi, rastgele $A-D$ olarak adlandırlan 4 ayrı grubu içermektedir: A (Novamin), B (1450 ppm $N a F$ and Novamin), C (CPP-ACP), D (1450ppm NaF). Örneklerde çürük benzeri oluşturduktan sonra her grupta günlük demineralizasyon ve remineralizasyon döngüsü 7 gün boyunca devam ettirilmiştir. Bu döngü esnasında her gruptaki örneklere seçilmiş değişik diş macunu uygulanmıştır. Diş minesinden mineral kaybı, örnek mine bloklarının yüzey mikrosertliği ile değerlendirilmiştir. Dört farkl macunun yüzey mikrosertlik geri kazanım (\%YMGK) miktarinin karşılaştırılması parametrik olmayan Kruskar-Wallis ile yapılmıştır. Bulgular: PIM ile yapılan ölçüm verileri ile örneklerin diş minesi üzerinde bir mineral çöküntü tabakası görülmüş fakat minedeki remineralizasyon tabakası arasında bir fark 
görülmemiştir ( $p>0,05)$. Sonuçlar benzer kaynaklı ve konsantrasyonlu fluorid içeren diş macunlarının değişik derecede remineralizasyona neden olduğunu göstermiştir. Sonuçlar: Novamin içerikli diş macunları, fluorid içerikli dişmacunları ile karşılaş̧tırıldığında çürük benzeri lezyonlarda benzer remineralizasyon potansiyeline sahiptir. Anahtar kelimeler: Diş macunu, diş remineralizasyon, diş demineralizasyon, in vitro teknikler, diş.

\section{REFERENCES}

1. Azarpazhooh A, Main PA. Fluoride varnish in the prevention of dental caries in children and adolescents: a systematic review. J Can Dent Assoc 2008;74:73-79. 2. Kato MT, Leite AL, Hannas AR, Oliveira RC, Pereira JC, Tjäderhane L, Buzalaf MAR. Effect of iron on matrix metalloproteinase inhibition and on the prevention of dentine erosion. Caries Res 2010;44:309316.

3. Kumar VL, Itthagarun A, King NM. The effect of casein phosphopeptide-amorphous calcium phosphate on remineralization of artificial caries-like lesions: An in vitro study. Aust Dent J 2008;53:34-40.

4. Queiroz CS, Hara AT, Paes Leme AF, Cury JA. $\mathrm{PH}$ cycling models to evaluate the effect of low fluoride dentifrice on enamel de- and remineralization. Braz Dent J 2008;19: 21-27.

5. Peters MC, Bresciani E, Barata TJ, Fagundes TC, Navarro RL, Navarro MF, Dickens SH. In vivo dentin remineralization by calcium-phosphate cement. J Dent Res 2010;89: 286-291.

6. Wiegand A, Krieger C, Attin R, Hellwig E, Attin T. Fluoride uptake and resistance to further demineralisation of demineralised enamel after application of differently concentrated acidulated sodium fluoride gels. Clin Oral Investig 2005;9:52-57.

7. Wong MC, Clarkson J, Glenny AM, Lo EC, Marinho VC, Tsang BW, Walsh T, Worthington HV. Cochrane reviews on the benefits/risks of fluoride toothpastes. J Dent Res 2011;90:573-579.

8. Passalini P, Fidalgo TK, Caldeira EM, Gleiser R, Nojima da C, Maia LC. Preventive effect of fluoridated orthodontic resins subjected to high cariogenic challenges. Braz Dent J 2010;21:211-215.

9. White DJ. Reactivity of fluoride dentifrices with artificial caries. I. Effects on early lesions: F uptake, surface hardening and remineralization. Caries Res 1987;21:126-140.

10. Poggio C, Grasso N, Ceci M, Beltrami R, Colombo M, Chiesa M. Ultrastructural evaluation of enamel surface morphology after tooth bleaching followed by the application of protective pastes. Scanning 2016;38:221-226.

11. Rodrigues E, Botazzo Delbem AC, Pedrini D, Cavassan L. Enamel Remineralization by FluorideReleasing Materials: Proposal of a pH-Cycling Model. Braz Dent J 2010;21:446-451.

12. Salonen J, Arjasmaa M, Tuominen U, Behbehani MJ, Zaatar EI. Bioactive glass in dentistry. J Minimum Interv Dent 2009;2:208-218.
13. Wefel JS. NovaMin: Likely clinical success. Adv Dent Res 2009;21:40-43.

14. Madan N, Madan N, Sharma V, Pardal D. Tooth remineralization using bio active glass-a novel approach. J Aca Adv Dent Res 2011;2:45-50.

15. Lynch RJ, Mony U, ten Cate JM. Effect of lesion characteristics and mineralizing solution type on enamel remineralization in vitro. Caries Res 2007;41:257-262.

16. Vieira AE, Delbem AC, Sassaki KT, Rodrigues E, Cury JA, Cunha RF. Fluoride dose response in $\mathrm{pH}-$ cycling models using bovine enamel. Caries Res 2005;39:514-520.

17. Meredith P, Donald, AM, and Thiel B. Electrongas interactions in the environmental SEM's gaseous detector. Scanning 1996; 18:467-473.

18. Gelhard TB, Arends J. In vivo remineralization of artificial subsurface lesions in human enamel. I. J Biol Buccale 1984;12:49-57.

19. Holmgren C, Gaucher C, Decerle N, Doméjean S. Minimal intervention dentistry II: part 3. Management of non-cavitated (initial) occlusal caries lesions--noninvasive approaches through remineralisation and therapeutic sealants. Br Dent J. 2014;216:237-243.

20. Singhal RK, Rai B. Remineralization Potential of Three Tooth Pastes on Enamel Caries. Open Access Maced J Med Sci. 2017;5:664-666.

21. Tschoppe P, Zandim LD, Martus P, Kielbassa MA. Enamel and dentine remineralization by nanohydroxyapatite toothpastes. J Dent 2011;39:430-437.

22. Abou Neel EA, Aljabo A, Strange A, Ibrahim S, Coathup M, Young AM, Bozec L, Mudera V. Demineralization-remineralization dynamics in teeth and bone. Int J Nanomedicine. 2016 Sep 19;11:47434763.

23. Aren G. Çocukta floridli diş macunu kullanımının yararları ve olası riskleri. TDBD 2014;140:74-79.

24. Madan N, Sharma V, Pardal D, Madan N. Tooth remineralization using bio-active glass - A novel approach. J Acad Adv Dent Res 2011;2:45-49.

25. Rao A, Malhotra N. The Role of Remineralizing Agents in Dentistry: A Review. Compend Contin Educ Dent 2011;32:26-33.

26. Gjorgievska ES, Nicholson JW, Slipper, IJ, Stevanovic MM. Remineralization of demineralized enamel by toothpastes: A scanning electron microscopy, energy dispersive X-ray analysis, and three-dimensional stereo-micrographic study. Microscopy and Microanalysis 2013;19:587-595.

27. Matsuyoshi S, Murayama R, Akiba S, Yabuki C, Takamizawa T, Kurokawa H, Miyazaki M. Enamel remineralization effect of a dentifrice containing calcium sodium phosphosilicate: an optical coherence tomography observation. Acta Odontol Scand 2017;75:191-197.

28. Palaniswamy UK, Prashar N, Kaushik M, Lakkam SR, Arya S, Pebbeti S. A comparative evaluation of remineralizing ability of bioactive glass and amorphous calcium phosphate casein phosphopeptide on early enamel lesion. Dent Res J 2016; 13: 297-302.

29. Mony S, Rao A, Shenoy R, Suprabha BS. Comparative evaluation of the remineralizing efficacy 
of calcium sodium phosphosilicate agent and fluoride based on quantitative and qualitative analysis. J Indian Soc Pedod Prev Dent 2015; 33: 291-295.

30. Rajan R, Krishnan R, Bhaskaran B, Kumar SV. A Polarized Light Microscopic Study to Comparatively evaluate Four Remineralizing Agents on Enamel viz CPP-ACPF, ReminPro, SHY-NM and Colgate Strong Teeth. Int J Clin Pediatr Dent 2015;8:42-47.

31. Mettu S, Srinivas N, Sampath CR, Srinivas N. Effect of casein phosphopeptide-amorphous calcium phosphate (cpp-acp) on caries-like lesions in terms of time and nano-hardness: An in vitro study. Journal of Indian Society of Pedodontics and Preventive Dentistry 2015;33: 269.

32. Narayana SS, Deepa VK, Ahamed S, Sathish ES, Meyappan R, Satheesh Kumar KS, Remineralization efficiency of bioactive glass on artificially induced carious lesion an in-vitro study, J Indian Soc Pedod Prev Dent 2014;32:19-25.

33. Golpayegani MV, Biria AM, Ansari G. Remineralization Effect of Topical NovaMin Versus Sodium Fluoride $(1.1 \%)$ on Caries-Like Lesions in
Permanent Teeth. Journal of Dentistry, Tehran University of Medical Sciences 2012;9:68-75.

34. Mehta AB, Kumari V, Jose R, Izadikhah V. Remineralization potential of bioactive glass and casein phosphopeptide-amorphous calcium phosphate on initial carious lesion: An in-vitro pH-cycling study. J Conserv Dent 2014;17:3-7.

35. Wang Y, Mei L, Gong L, Li J, He S, Ji Y, Sun W. Remineralization of early enamel caries lesions using different bioactive elements containing toothpastes: An in vitro study. Technol Health Care 2016;24:701-711.

36. Assunção CM, Goulart $M$, Essvein TE, Santos NMD, Erhardt MCG, Lussi A, Rodrigues JA. Effect of erosive challenges on deciduous teeth undergoing restorative procedures with different adhesive protocols: an in-vitro study. J Appl Oral Sci. 2018;26: e20170053.

37. Gutiérrez SB, Reyes GJ. Microhardness and Chemical Composition of Human Tooth. Materials Res 2003;6:367-373.

38. Bakry AS, Marghalani HY, Amin OA, Tagami J. The effect of a bioglass paste on enamel exposed to erosive challenge. J Dent 2014;42:1458-1463. 